\title{
Correction: A rare case of dual diagnosis in a 16-year-old girl with shortness of breath
}

de Vere F, House R, Gokdogan Y. A rare case of dual diagnosis in a 16-year-old girl with shortness of breath. BMJ Case Reports 2017. doi:10.1136/bcr-2017-221939.

There was an error in the published version of this article, in that the following statement was missed from the publication:

FDV and RH are joint first authors and contributed equally to this paper.

(C) BMJ Publishing Group Ltd (unless otherwise stated in the text of the article) 2018. All rights reserved. No commercial use is permitted unless otherwise expressly granted.

BMJ Case Rep 2018. doi:10.1136/bcr-2017-221939corr1

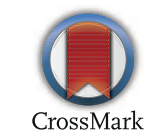

Copyright 2017 BMJ Publishing Group. All rights reserved. For permission to reuse any of this content visit http://group.bmj.com/group/rights-licensing/permissions.

BMJ Case Report Fellows may re-use this article for personal use and teaching without any further permission.

Become a Fellow of BMJ Case Reports today and you can:

- Submit as many cases as you like

- Enjoy fast sympathetic peer review and rapid publication of accepted articles

- Access all the published articles

Re-use any of the published material for personal use and teaching without further permission

For information on Institutional Fellowships contact consortiasales@bmjgroup.com

Visit casereports.bmj.com for more articles like this and to become a Fellow 